\title{
2-DIMENSIONAL MODELING OF HIGH-RESOLUTION AEROMAGNETIC DATA OVER YOLA ARM OF THE UPPER BENUE TROUGH, NORTHEASTERN NIGERIA
}

MUSA HAYATUDEEN, NSIKAK E. BASSEY, BELLO RASAQ

(Received 3 November 2020; Revision Accepted 2 February 2021)

\begin{abstract}
2-D modeling of high-resolution aeromagnetic data over the area investigated was carried out with the aid of Oasis Montaj $^{T M}$ software in order to get the total magnetic intensity map as well as the residual map from where the modeling was carried out. The data was acquired for Nigeria Geological Survey Agency (NGSA) in 2010 by Fugro international of Netherlands. The specifications of the data were terrain clearance of $80 \mathrm{~m}$, flight line spacing of $500 \mathrm{~m}$ and a tie line spacing of $5000 \mathrm{~m}$. The area investigated in this work is located between longitude $12^{0} 00^{\prime}-13^{0} 30^{\prime} \mathrm{E}$ and Latitude $8^{0}$ $00^{\prime}-10^{\circ} 00^{\prime} \mathrm{N}$. GM-SYS module of the Oasis montaj was used for this research, with depocentres, structural patterns, basement geometry and morphology as well as estimates of the physical character of the cause to an investigated anomaly determined. The models reveal the horst and graben structures of the basement and the various faults that segmented the area into block patterns. The results revealed sediment thickness in the range of $2-5 \mathrm{~km}$ for the models which are in agreement with the results obtained by various researchers in the area. Horst and graben were identified in the models which confirmed the rifting nature of the Benue Trough. The authors of this research are of the view that these depocentres, structural patterns and basement geometry may be a promising site for hydrocarbon traps and reservoirs.
\end{abstract}

KEYWORDS: Aeromagnetic Data, GM-SYS, Modeling, Horst, Graben.

\section{INTRODUCTION}

Geophysical survey using airborne approach is an important aspect of modern geophysics which enables faster, cheaper and wider coverage of the exploration area (Ugwu et al., 2018). The high-resolution aeromagnetic data utilized for this work was acquired over the Yola Trough and surroundings of the basement blocks (Figure 1), in which a 2-dimensional modeling of the subsurface structures (horst and graben) was carried out.

The area investigated in this work is located between longitudes $12^{\circ} 00^{\prime}-13^{\circ} 30^{\prime} \mathrm{E}$ and Latitudes $8^{\circ} 00^{\prime}-10^{\circ}$ $00^{\prime} \mathrm{N}$, a Yola trough which is a division of the upper Benue trough and a sub set of the Benue trough, a Cretaceous sedimentary basin, trending in E-W direction. The trough is an important arm of the Benue trough formed by a number of sub basins of which development and spreading were controlled by fracture system where the $N 55^{\circ} \mathrm{E}$ Benue trend is dominant in the whole trough and nearby basement. A massive phase of Maestrichtian age was responsible for the development of the Cretaceous cover. The drainage channel for local rivers in the area has its source eastward from Cameroon while other rivers drain out through the Gongola River. Yola trough is part of the upper Benue trough and confined by the Hawal basement and the Adamawa Massif to the north and south respectively with the two Massifs spreading out into Cameroon Republic. Notable towns in the region are Yola, Sugu, Song, Ganye and Toungo. Researches carried out by previous researchers include analysis by Udensi and Usazuwa (2002) on "the $2 \frac{1}{2}$

Musa Hayatudeen, Department of Physics, Federal University of Kashere, Gombe state, Nigeria.

Nsikak E. Bassey, Department of Geology, Akwa Ibom state University, Mkpat Enin, Uyo, Nigeria.

Bello Rasaq, Department of Physics, Federal University of Kashere, Gombe state, Nigeria. 
dimensional modeling of the major structure underlying the Nupe basin Nigeria, using aeromagnetic data". They inferred that the basin had extensive sediment thickness and recommended the basin for further exploration using seismic reflection for hydrocarbon accumulation".

Values from magnetic basement depth from spectral technique and slope techniques using high resolution aeromagnetic data by Nwosu et al., (2015) revealed regions of high and low frequency anomalies which were associated with shallow and deep seated bodies." Geomagnetic modeling of potential hydrocarbon traps in the lower Niger delta off shore West Africa" by Ali et al., (2012) recommended regions of structural low for detail prospecting in the new frontiers using seismic method.

Working in the upper Benue trough utilizing aeromagnetic data, (Ofoegbu, 1988) concluded that "the magnetic anomalies over the area can best be deciphered in terms of combined effects of intrusive bodies and a crystalline basement of variable topography". Guiraud, (1990) who worked on the Bima formation in the upper Benue trough thought that the lower Bima sediment deposit was in a horst and graben environment. Braide (1992) in his work on sedimentation and tectonics concluded that the Yola basin was conceivably made as a result of pull apart basin.

\section{GEOLOGY OF THE AREA}

The Yola trough is a Cretaceous sedimentary sub-basin that forms a narrow band of terrains which stretches eastward and splits into small isolated basins in
Studies on "2-D modeling of subsurface structure over upper Benue trough and Borno basin northeastern Nigeria", (Salako and Udensi, 2015) established the possibility of existence of hydrocarbon in the region which was reinforced by the presence of thick sediments couple with the nature of existing geological patterns.

Magnetic indication for relations between basement tectonic and hydrocarbon reservoir in the Niger delta Nigeria by Oladele et al., (2008) indicated that the "morphology and structures of the area influence the tectonics and hydrocarbon occurrences within the sedimentary section". Likewise dealing with the "2-D and 3-D modeling of magnetic and resistivity data for Äspö" by Hakan, (2011) established the deformation zones and rock units in the area.

The aim of this research was to examine the high resolution aeromagnetic data over the region investigated to determine promising locations for hydrocarbon traps and reservoirs. The target of this study was to determine depocentres, (in form of graben), structural patterns, basement geometry and morphology and also to appraise the physical features of the cause to an investigated anomaly (by appraising the depth and dimensions of the source of anomalies.

Cameroon. The sedimentary rocks are shales, sandstones, limestones, siltstone and clay, extrusive rocks are found within the sedimentary basin and in the basement.

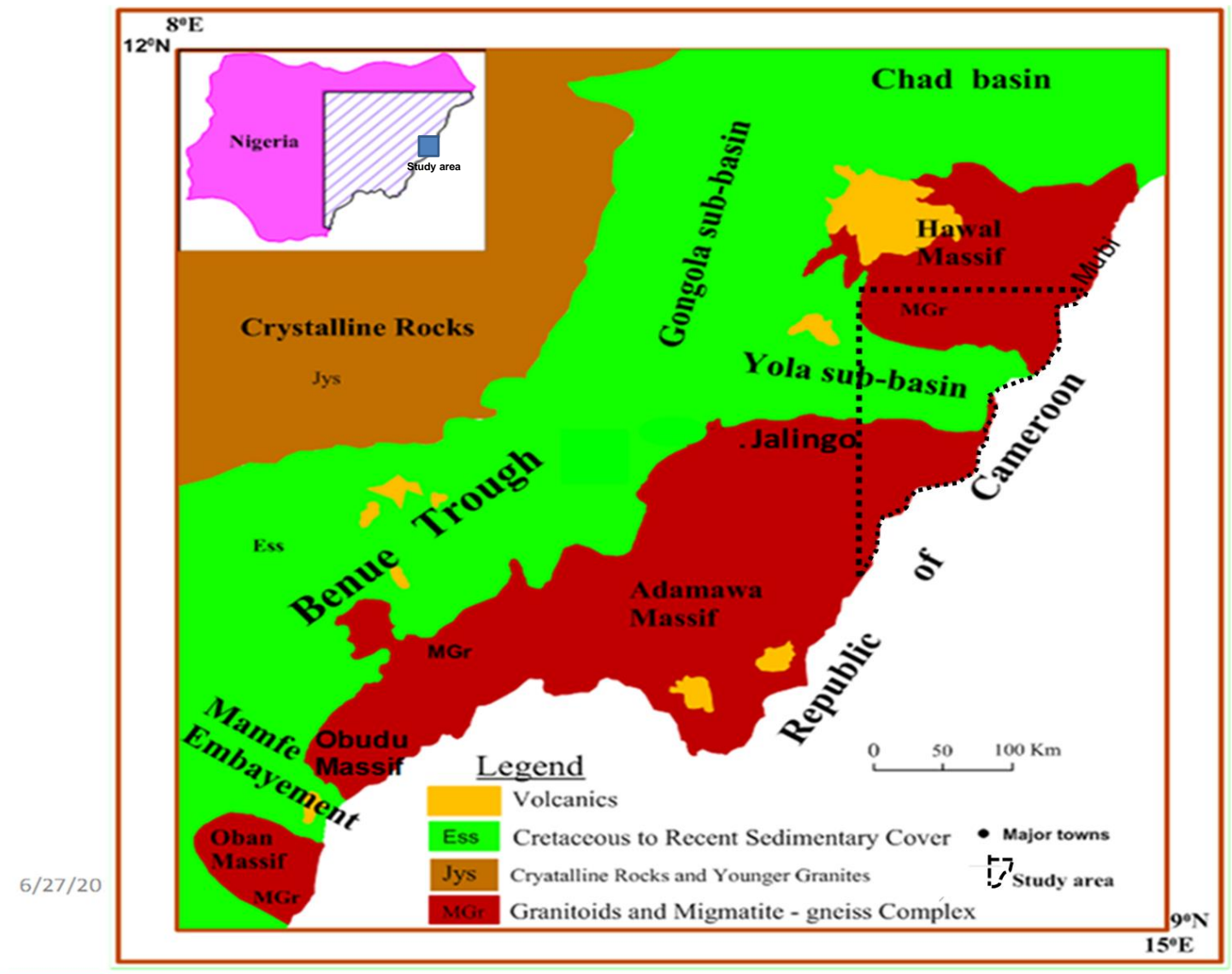

Figure 1. Map of study area. (Adapted from Haruna et al., 2011) 


\section{Materials and Method}

The aeromagnetic data used in this work was acquired for Nigeria Geological Survey Agency (NGSA) in 2010 by Fugro international of Netherlands. The specifications of the data were terrain clearance of $80 \mathrm{~m}$, flight line spacing of $500 \mathrm{~m}$ and a tie line spacing $5000 \mathrm{~m}$. The index numbers of the sheets used were $175,176,177,196,197,217,218$ and 238 . Total magnetic intensity map (figure 2) and residual map (figure 3) were obtained by utilizing Oasis Montaj ${ }^{T M}$ software. Regionalresidual separation was carried out using the polynomial fitting. Here, the regional was matched with a mathematical (polynomial) of low order to expose the residual features as random errors, and the treatment was based on statistical theory. The least square method was chosen as a mathematically tool to give the closest fit to the magnetic field that can be obtained within a specified degree of freedom. This regional field is the difference between the residual field and the magnetic field. GM-SYS module of the Oasis montaj software was utilized for the modeling exercise which make use of the calculation describe by Won and Bevis, (1987) "the program compares a theoretical anomaly with successive fits improvement until best possible fit was obtained". Some of the depth estimates from other methods suffers from various constrains according to (Ramadas et al., 2004) on the grounds that "they cannot

$$
\begin{aligned}
& M_{1}=\frac{\Delta y(\text { Log } E)}{\Delta x(\text { Freq. })} \\
& M_{2}=\frac{\Delta y(\text { Log } E)}{\Delta x(\text { Freq. })} \\
& D_{1}=\frac{-M_{1}}{2 \pi} \\
& D_{2}=\frac{-M_{2}}{2 \pi}
\end{aligned}
$$

accurately map the undulations of the basement topography as they give only the average depths".

The modeling carried out in this work utilized power spectrum method of spectral analysis which was broken into series of straight line segments, each segment represents the aggregate response of an ensemble of sources at a given depth. The depth was directly proportional to the slope of the line segment. According to Keary et al., (2004), "the slope of each segment provided information about the depth to the top of an ensemble of magnetic bodies". The amplitude of the logarithm of the radially average power spectrum was plotted against the radial frequency. The linear segments of the spectrum corresponded to separate depth ensembles. Region investigated in this work was divided into eight blocks, each block measures $15^{\circ} \times 15^{0}$ which was used to obtain radial average power spectrum.

According to Ugwu et al., (2018), "the discrete Fourier transform numerical instrument utilized for spectral analysis and applied to regularly spaced data such as the aeromagnetic data to calculate and decipher the spectrum of the potential field". To perform this investigation, "graphs of the natural logarithms of the amplitude against frequency were plotted and the gradient of the linear segments computed in order to acquire the depths to the basement by utilizing the equations" of Ugwu et al., (2018)

where $M_{1}$ and $M_{2}$ are the slopes of the first and second segments of the plots. The negative sign shows depth to the subsurface while $D_{1}$ (deep depth) and $D_{2}$ (shallow depth) are the first and second depth segments, respectively.

Bhattacharyya (1966) determined the expression for the power spectrum of the total magnetic field intensity anomaly over a single rectangular square as an element of the spatial frequencies $u, v$ (radians $/ \mathrm{km}$ ) in the $x$ and $y$-directions. A generalized expression used by Salem et al., (2000) in which the energy spectrum of the map in polar coordinates

$$
\langle E(r, \theta)\rangle=4 \pi^{2} M^{2} R_{G}^{2}\left\langle e^{-2 h r}\right\rangle\left\langle\left(1-e^{-t r}\right)^{2}\right\rangle\left\langle S^{2}(r, \theta)\right\rangle\left\langle R_{P}^{2}(\theta)\right\rangle
$$

where $<>$ is expected value

$r=\left(u^{2}+v^{2}\right)^{1 / 2}=$ frequency vector amplitude,

$\theta=\tan ^{-1} u / v=$ frequency vector direction,

$M=$ magnetic moment/unit depth,

$h=$ depth to the top of the prism,

$t=$ prism thickness,

$S=$ factor for the horizontal size of the prism,

$R_{P}=$ factor for magnetisation of prism, and

$R_{G}=$ factor for geometric field direction. 
Taking the average with respect to $\theta$ gives

$$
\langle\bar{E}(r)\rangle=4 \pi^{2} M^{2} \bar{R}_{G}^{2}\left\langle e^{-2 h r}\right\rangle\left\langle\left(1-e^{-t r}\right)^{2}\right\rangle\left\langle\bar{S}^{2}(r)\right\rangle
$$

Where $\bar{E}, \bar{R}$, and $\bar{S}$ indicate the average over $\theta$.

In this investigation, three initial model parameters were used, the contact/basement boundary blocks that were identified from power spectrum and source parameter imaging by Musa, (2018), depth to the bottom of the magnetic source was estimated from power spectrum and existing geologic information.
Susceptibility value was assigned to each part of the model. Total contributions of each block along the profile was a function of the anomaly. Four pieces of information were required for the modeling (a) susceptibility (b) magnitude (c) top surface (d) bottom surface. Any of the above could be calculated if three of the other parameters are known or assumed.
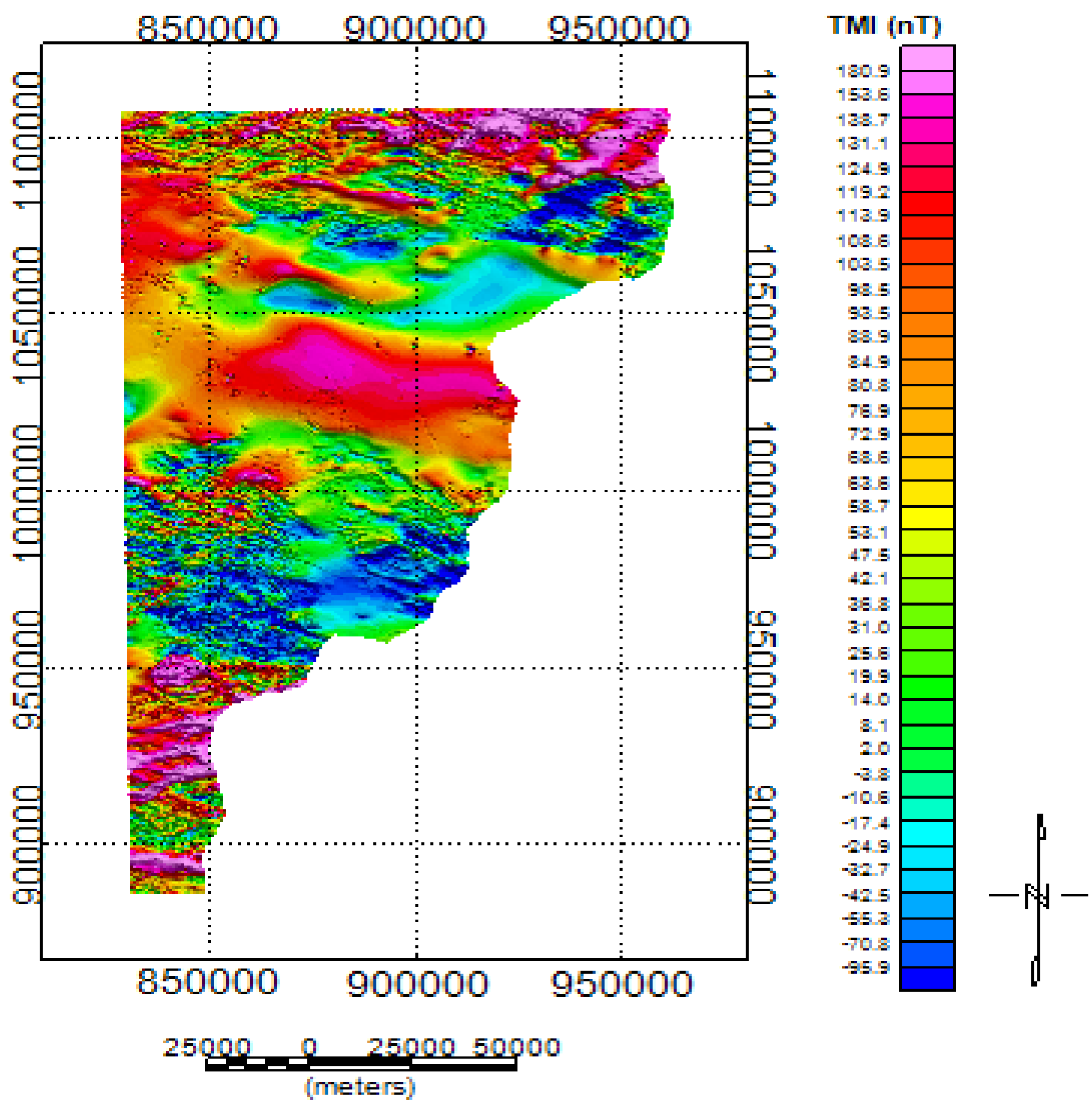

Figure 2. Map of total magnetic intensity of the region. 


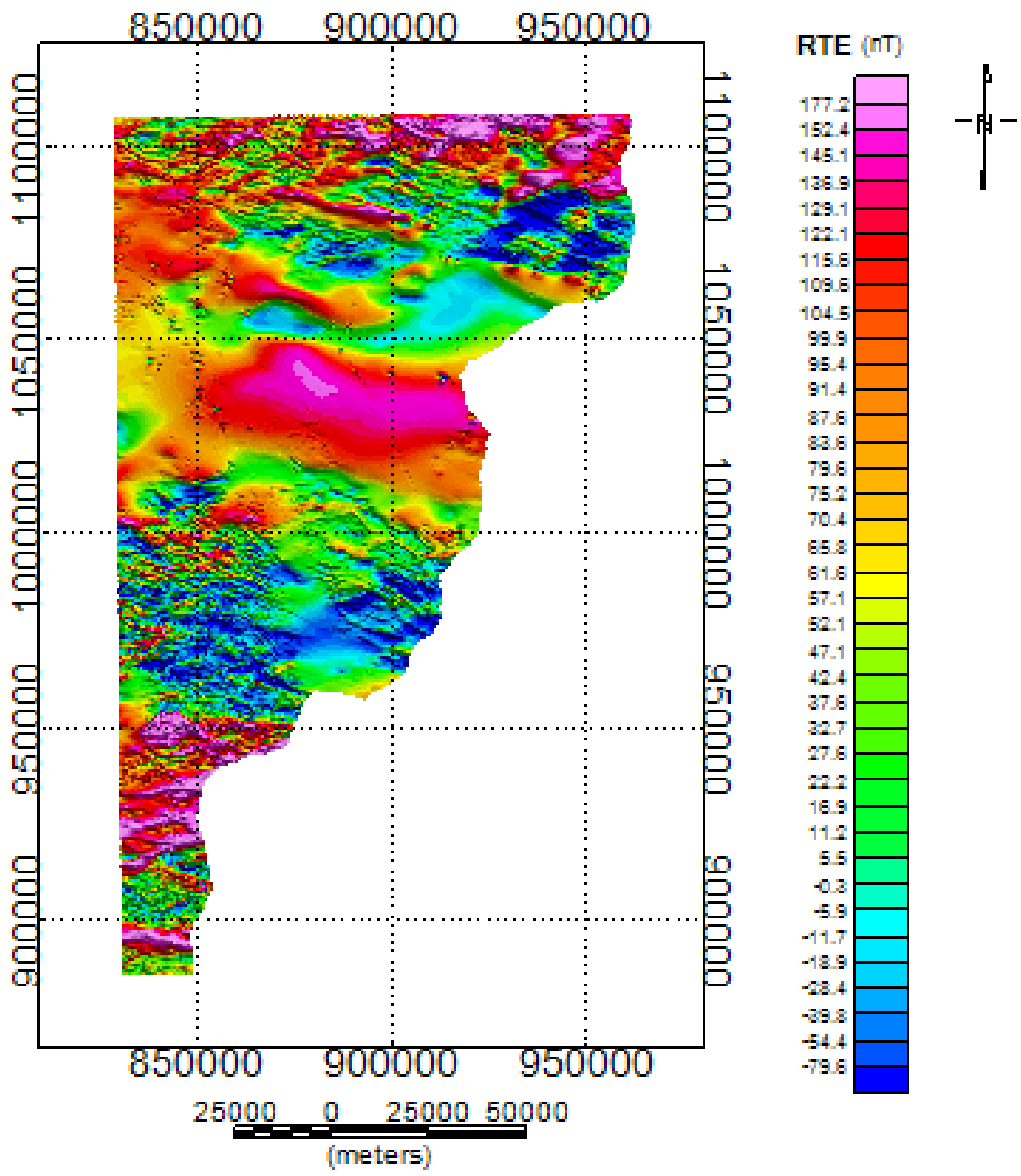

Figure 3. Map of residual aeromagnetic of the region investigated.

\section{RESULTS AND DISCUSSION}

\section{Results}

Four profiles were sketched on the map of residual magnetic anomaly of the region investigated across noticeable anomalies (figure 4), this enables assessment of physical character and geometry of the cause to noticeable anomaly. The anomalies were revealed based on the known information of the geology of the region, depths to basement were modified iteratively in order to reduce error and obtain the best fit. Total field strength of $34132 \mathrm{nT}$, declination of -0.065 degrees and inclination of -3.5 degrees were used during modeling to obtain magnetic field reactions. 


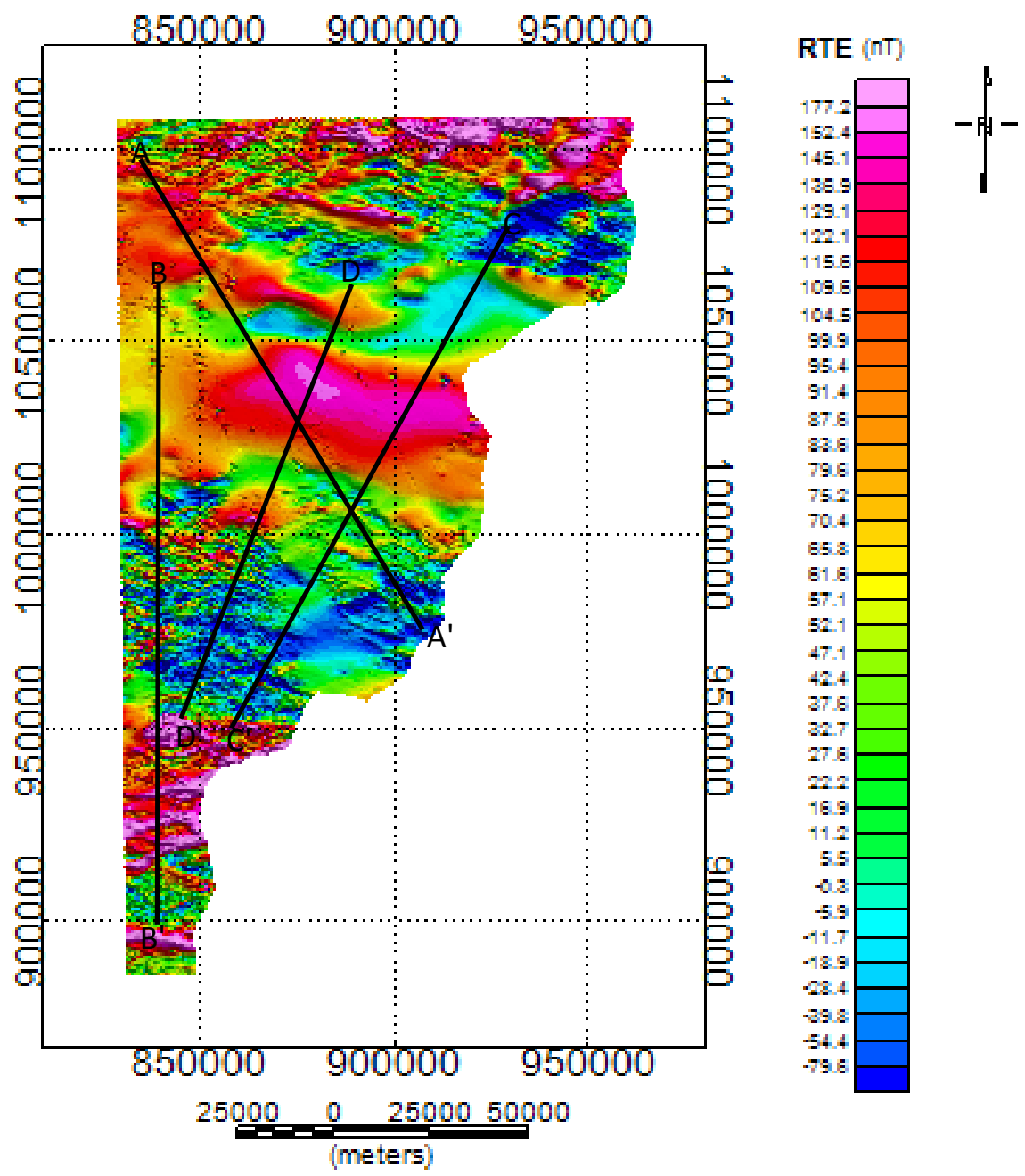

Figure 4. Residual aeromagnetic map of the region investigated with the profile drawn on it.

Table 1. Modeling parameters.

\begin{tabular}{lcclllll}
\hline Profiles & $\begin{array}{l}\text { Incli } \\
\text { nation } \\
\left({ }^{0}\right)\end{array}$ & $\begin{array}{l}\text { Decli } \\
\text { nation } \\
\left({ }^{0}\right)\end{array}$ & $\begin{array}{l}\text { Total } \\
\text { Field } \\
(\mathrm{nT})\end{array}$ & $\begin{array}{l}\text { No. Of } \\
\text { basem } \\
\text { ent } \\
\text { blocks }\end{array}$ & $\begin{array}{l}\text { Magnetic } \\
\text { Susceptibility } \\
\text { of sedimentary } \\
\text { rocks (c.g.s) }\end{array}$ & $\begin{array}{l}\text { Magnetic } \\
\text { Susceptibility } \\
\text { of basement } \\
\text { rocks (c.g.s) }\end{array}$ & $\begin{array}{l}\text { No. of } \\
\text { of } \\
\text { subsurface } \\
\text { Intrusives }\end{array}$ \\
\hline A-A' $^{\prime}$ & -3.5 & -0.065 & 34,132 & 12 & $0.001-0.03$ & $0.00001-0.001$ & 9 \\
B-B' $^{\prime}$ & -3.5 & -0.065 & 34,132 & 13 & $0.001-0.03$ & $0.00001-0.001$ & 8 \\
C-C' $^{\prime}$ & -3.5 & -0.065 & 34,132 & 15 & $0.001-0.03$ & $0.00001-0.001$ & 6 \\
D-D' & -3.5 & -0.065 & 34,132 & 8 & $0.001-0.03$ & $0.00001-0.001$ & 12 \\
\hline
\end{tabular}


Table 2. Magnetic susceptibility values of some materials (modified after Ali et al., 2012)

\begin{tabular}{ll}
\hline Rock (minerals) & Susceptibility (c.g.s.) \\
\hline Magnetite & $0.3-0.8$ \\
Pyrrhotite & 0.028 \\
Ilminite & 0.044 \\
Iron formation & 0.056 \\
Basalt & 0.00295 \\
Rhyolite & 0.00112 \\
Granite & 0.00047 \\
Other acid intrusives & 0.00035 \\
Sedimentary & $0.00001-0.001$ \\
& \\
\hline
\end{tabular}

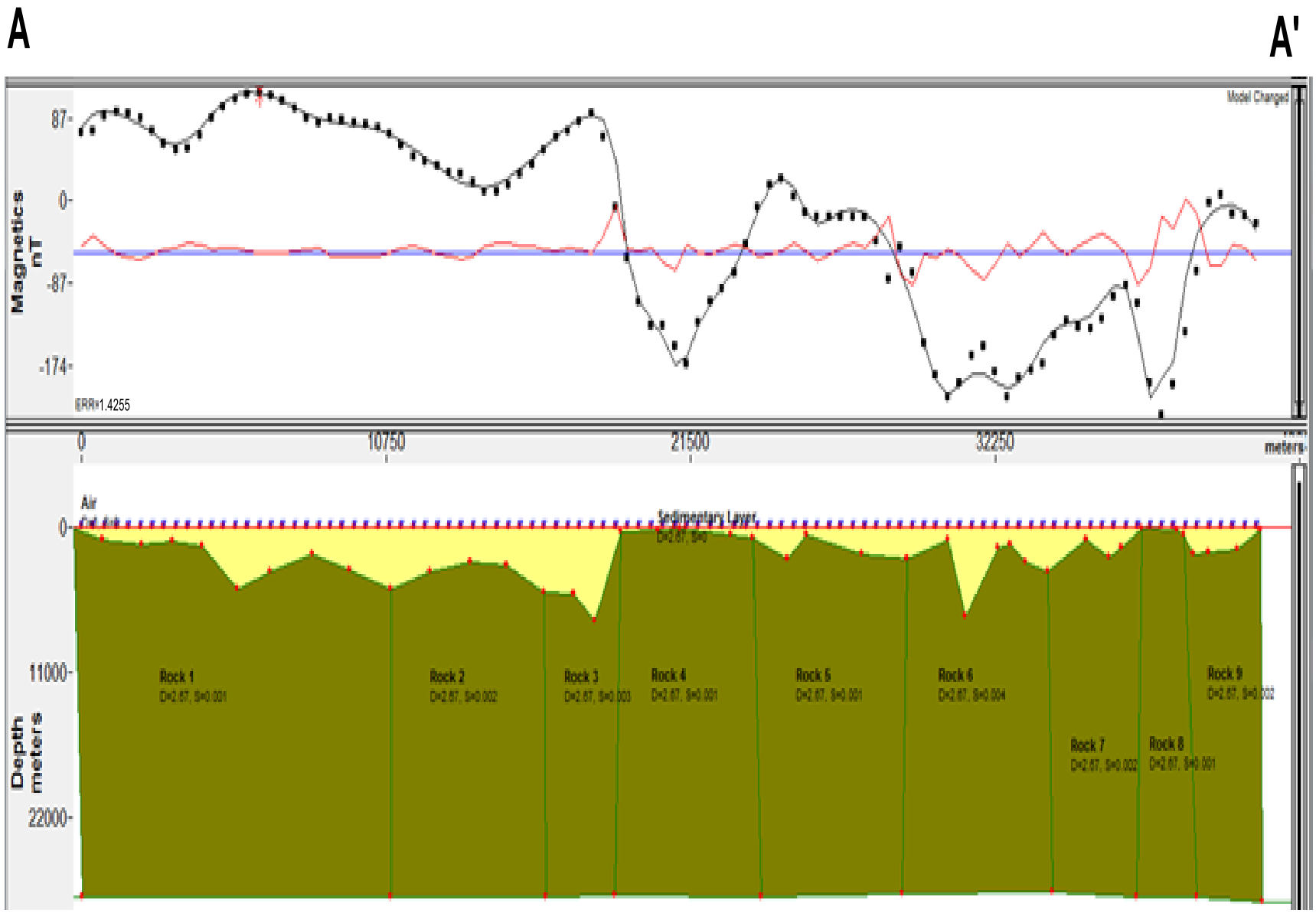

Figure 5. Modeled magnetic profile A-A'. Horizontal Scale: 0, 10750, 21500, 32550. Vertical Scale: 0, 11000, 22000 metres. 
B

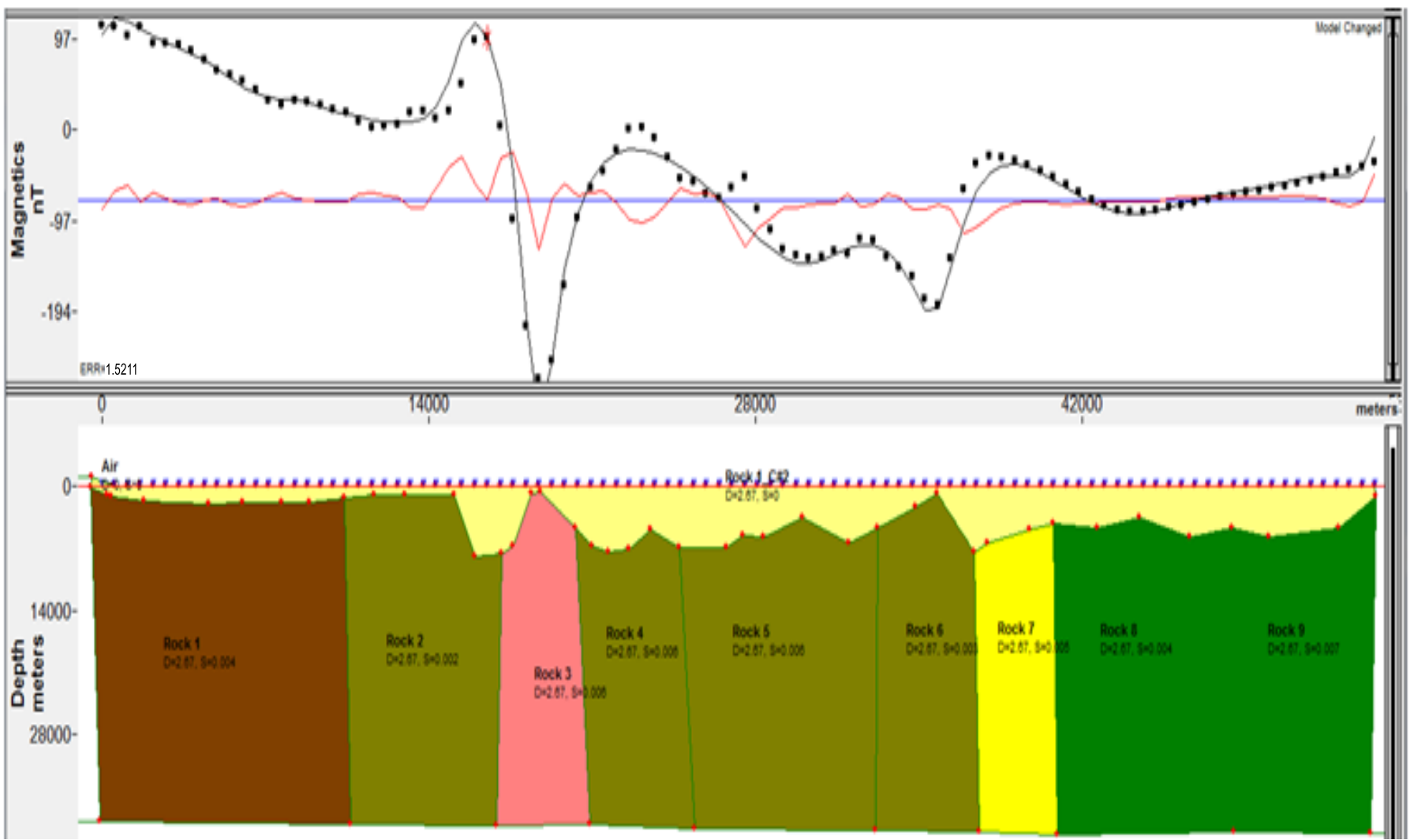

Figure 6. Modeled magnetic profile B-B'. Horizontal Scale: 0, 14000, 28000, 42000. Vertical Scale: 0, 14000, 28000 metres.

C

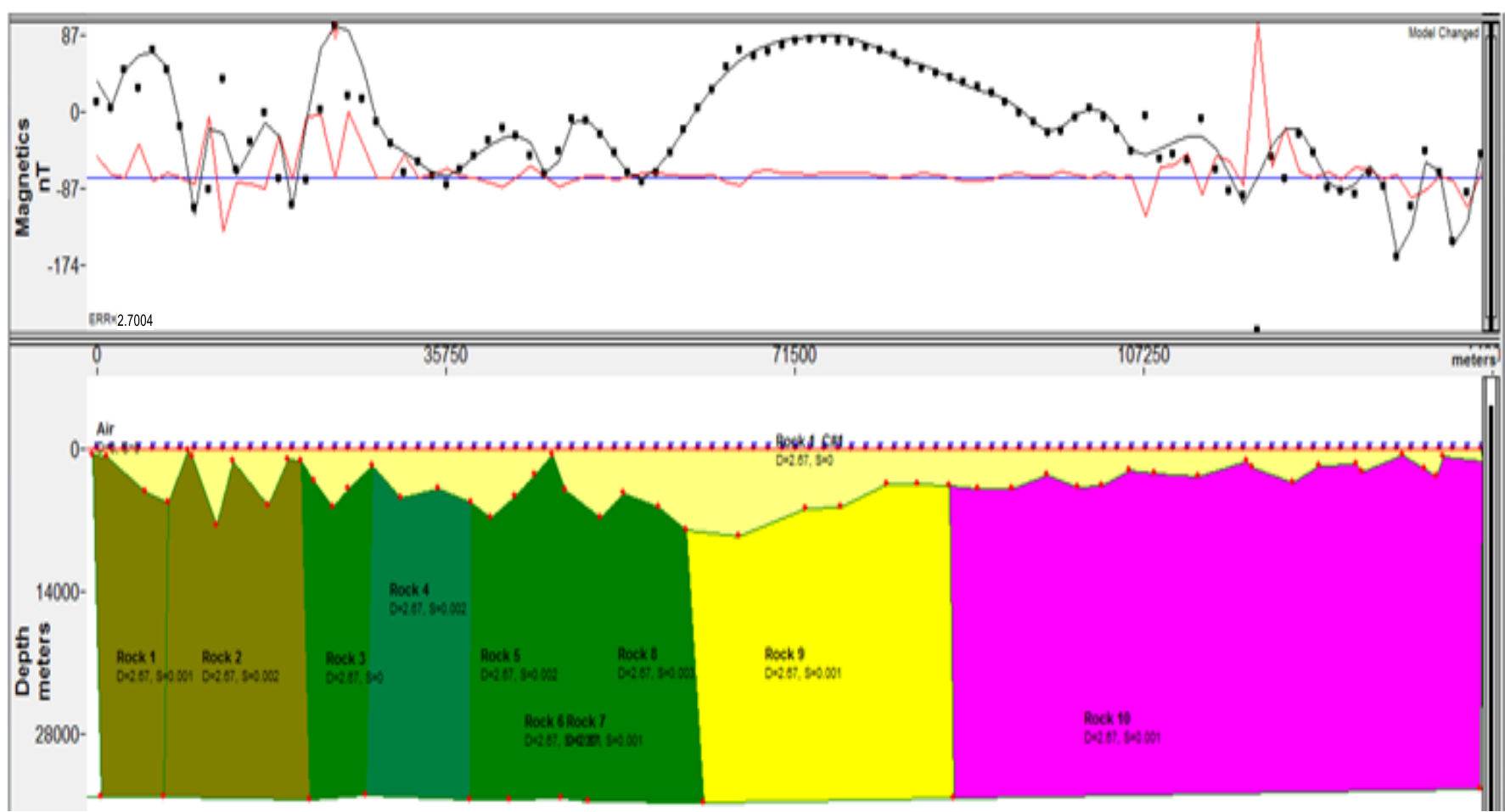

Figure 7. Modeled magnetic profile C-C'. Horizontal Scale: 0, 35750, 71500, 107250. Vertical Scale: 0, 14000, 28000 metres. 
D

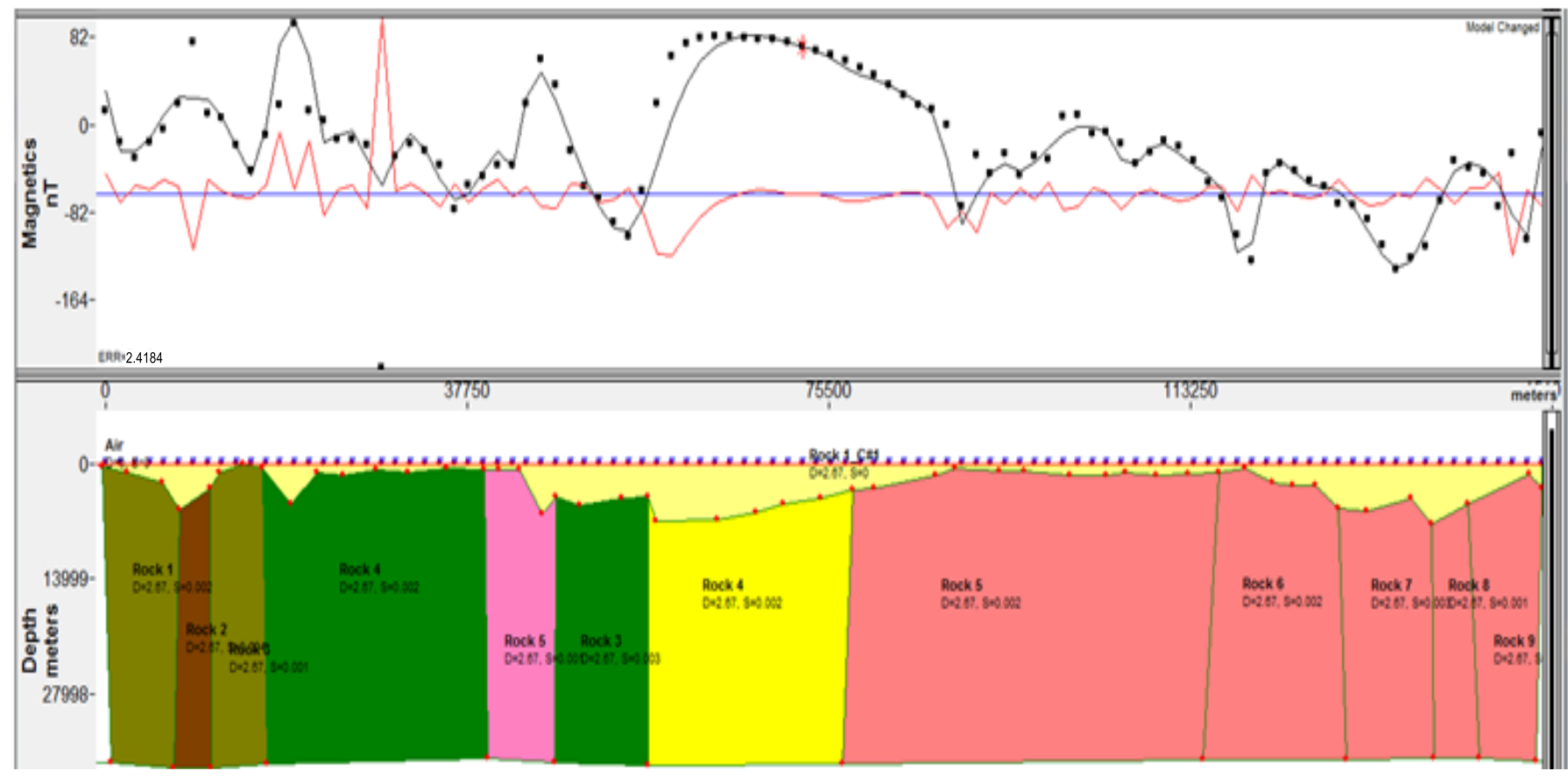

Figure 8. Modeled magnetic profile D-D'. Horizontal Scale: 0, 37750, 75500, 113250. Vertical Scale: 0, 13999, 27998 metres.

\section{DISCUSSION}

\section{Modeled profile A-A'}

This model cut across the region investigated in the NWSE direction (figure 5), indicating a good fit between modeled and experimental magnetic profiles with an error of $1.42 \%$. This profile was computed as nine (9) blocks i.e. rocks 1 - 9 (figure 5). The down faulted blocks (graben) and the uplifted blocks (horst) which gave rise to wave - like nature of the basement topography, was caused by movement along the blocks. The structural contacts or lithologies observed in rocks $1-9$ were indicated by the green lines separating the rocks. Depth of $28 \mathrm{~km}$ was computed for the profile with sediment thickness of less than $4 \mathrm{~km}$. A wide graben noticed in the left hand side which was deduced to be faults or joints or lithologic contact which have slightly moved in relation to the adjoining blocks.

\section{Modeled profile B-B}

The model cut across the region investigated in the N-S direction (figure 6), indicating a good fit between the modeled and experimental magnetic profiles with an error of $1.52 \%$. The profile was computed as eight (8) blocks i.e. rocks 1 - 8 (figure 6). The down faulted blocks (graben) and uplifted blocks (horst) which gave rise to wave - like nature of the basement topography, was caused by movement along the blocks. The lithologies observed in rocks $1-8$ were indicated by the green lines separating the rocks. Depth of $30 \mathrm{~km}$ was computed for the profile with sediment thickness of less than $4 \mathrm{~km}$. A wide graben noticed in the right hand side which was interpreted to be faults or lithologic contact which have slightly moved relative to the adjoining blocks.

\section{Modeled profile C-C'}

The model cut across the region investigated in the NESW direction (figure 7), indicating a good fit between the modeled and experimental magnetic profiles with an error of $2.7 \%$. The profile was computed as six (6) blocks i.e. rocks 1-6 (figure 7). The down faulted blocks (graben) and uplifted blocks (horst) which gave rise to wave - like nature of the basement topography, was caused by movement along the blocks. The structural contacts or lithologies observed in rocks $1-6$ were indicated by the green lines separating the rocks. Depth of $30 \mathrm{~km}$ was computed for the profile with sediment thickness of less than $5 \mathrm{~km}$. A wide graben was noticed at the middle of the model which was interpreted to be faults or joints or lithologic contact which have slightly progressed relative to the adjoining blocks.

\section{Modeled profile D-D'}

The model cut across the region investigated in the NESW direction (figure 8), indicating a good fit between the modeled and experimental magnetic profiles with an error of $2.42 \%$. The profile was computed as twelve (12) blocks i.e. rocks $1-12$ (figure8). The down faulted blocks (graben) and uplifted blocks (horst) which gave rise to wave - like nature of the basement topography, was caused by movement along the blocks. The structural contacts or lithologies observed in rocks $1-12$ were indicated by the green lines separating the rocks. Depth of $31 \mathrm{~km}$ was computed for the profile with sediment thickness of less than $2 \mathrm{~km}$. A little graben was noticed both in the left and right hand side which was interpreted to be faults or joints or lithologic contact which have slightly progressed relative to the adjoining blocks.

Results obtained by (Omeje et al., 2012) in the same area utilizing the GM-SYS computer modeling indicated 
that the sediment thickness varies between $0.9 \mathrm{~km}$ to $2.9 \mathrm{~km}$. Results obtained by (Ofoegbu et al., 1992; Okereke and Ofoegbu, 1992) utilizing gravity and magnetic data over the study area inferred that the basement was of irregular topography that was folded and uplifted in places. Likewise analysis on the stratigraphic progression of the Benue trough and its inference for upper Cretaceous palaeogeography of West Africa by (Peters, 1978) indicated that the region comprised three depositional structures analogous to graben and transitional tectonic periods.

The residual map and the models provided facts about the basement configuration, sediment thickness and distribution of faults. The region is suggested for comprehensive prospecting of hydrocarbon.

Modeling of aeromagnetic data was carried out to reveal depocentres, structural patterns, basement geometry and morphology. This comprises making numerical appraisal of the dimensions and depth of the anomalies. Conceptual models of the surfaces were established and their anomalies computed in order to deduce if the earth model was the same with theoretical and model anomalies. In this study four (4) profiles were drawn across prominent anomalies in the residual aeromagnetic map. The result showed that most of the models were in the range of $2-5 \mathrm{~km}$ which is in agreement with the results of the radially average power spectrum and source parameter imaging of the region investigated. Horst and graben were identified in the models which confirm the rifting nature of the Benue trough.

\section{CONCLUSION}

This research was carried out to outline depocentres, structural patterns, basement geometry and morphology and assess physical character of causative body to observed anomaly using high resolution aeromagnetic data. Oasis Montaj ${ }^{\mathrm{TM}}$ software was utilized on the data to get map total magnetic intensity and residual map from where the modeling was done. The residual data or map showed the long wavelength features which were due to deep seated sources. The residual map and the models gave clue about the basement structure, distribution of faults and sediment depth. In this study, four (4) profiles were drawn through noticeable anomalies in the residual aeromagnetic map and modeling was carried out.

The models gave insight on the horst and graben nature of the basement and the numerous faults that partitioned the basement into block patterns. The outcomes indicated sediment thickness in the range of $2-5 \mathrm{~km}$ for the models which is in concurrence with the earlier research outcomes in the region investigated. Horst and graben were recognized in the region which confirmed the rifting nature of the Benue trough. The authors of this research were of the view that these depocentres, structural patterns and basement geometry may be an ideal site for hydrocarbon traps and reservoirs.

\section{REFERENCES}

Ali I, Olatunji S, Nwankwo L. I, Akoshile C. O, Johnson L. $M$ and Edino F., 2012. Geomagnetic modeling of potential hydrocarbon traps in the lower Niger delta, off shore West Africa. Archives of applied science research. 4(2):863874.

Bhattacharyya B. K., 1966. Continuous spectrum of the total magnetic field anomaly due to a rectangular prismatic body. Geophysics, 31: 197-212.

Braide S. P., 1992. Studies on the sedimentation and tectonics of the Yola arm of the Benue trough facie architecture and their tectonic significance. Journal of mining and geology. 28(1):23-31.

Guiraud M. 1990. Tectono-sedimentary frame work of the early Cretaceous continental Bima formation upper Benue trough northeastern Nigeria. Journal of the African earth sciences. $1(1 / 2): 341-352$.

Hakan M, 2011. 2D and 3D modeling of magnetic and resistivity data from Äspö. SKB Box 250 SE 101-24 Stockholm Sweden. 11-19:1-29.

Haruna I. V, Orazulike D. M, Ofulume A. B., 2011. Preliminary geological and radiometric studies of granitoids of Zing-Monkin area, Adamawa Massif. NE Nigeria Global Journal of Geological Science, 9(2): 123-134.

Keary P, Brooks M, Hill I., 2004. An introduction to geophysical exploration, Blackwell publishing company, 9600 Garsington road, Oxford. OX4 2DQ, UK. 10 and 158.

Musa H., 2018. Interpretation of high resolution aeromagnetic and satellite data over upper Benue trough northeastern Nigeria. Unpublished Ph D Thesis, department of geology Modibbo Adama University of Technology Yola.

Nwosu O. B, Umego M. N, Onuba L. N., 2015. Comparison of magnetic basement depth values from spectral technique, source parameter imaging technique and slope techniques using High resolution aeromagnetic data over middle Benue trough Nigeria. Journal of Geology and Geophysics 4(6):.2-7. 
Ofoegbu C. O., 1988. An aeromagnetic study of part of upper Benue trough, Nigeria. Journal of the African earth sciences. 7(1):77-90.

Ofoegbu C. O., Odigi M. I., Ebinro J. O., 1992. On the tectonic evolution of the Benue trough (in $\mathrm{C}$. O Ofoegbu edition) the Benue Trough structure and evolution. International monograph Series, Earth evolutionary science.203-216.

Okereke C. S., Ofoegbu C. O., 1992. Gravity and magnetic data over the Yola arm of the upper Benue trough (in C.O Ofoegbu) The Benue trough structure and evolution. International, Monograph, Series, Earth Evolutionary Science :171-202.

Oladele S, Ojo S. B, Ako, B. D., 2008. Magnetic evidence for links between basement tectonics and hydrocarbon reservoirs in the Niger delta Nigeria. NAPE extended abstract, proceedings from the 2008 NAPE conference.11-13.

Omeje M, Ibrahim N. B, Meludu O, Paulinus E. U., 2012. $2^{-1 / 2}$ Dimensional modeling of the major structures underlying Dong and Shelleng of the upper Benue valley, using GM-SYS computer modeling. Journal of Natural Sciences Research 2 (5):50-68.

Petters S. W., 1978 Stratigraphic evolution of the upper Benue trough and its implication for the upper Cretaceous paleogeography of West Africa. Journal of geology, University of Chicago. 86: 311-322.
Salako K. A, Udensi E. E., 2015. Two dimensional modeling of subsurface structure over upper Benue trough and Borno basin in northeastern Nigeria. Nigerian journal of technological research. (Special edition) 10:94-104.

Salem A, Ushijima K, Elsirafi A, Mizunaga H., 2000. Spectral Analysis of Aeromagnetic Data for Geothermal Reconnaissance of Quseir Area, Northern Red Sea, Egypt. Proceedings World Geothermal Congress, Kyushu - Tohoku, Japan.

Ramadas G, Himabindu D, Ramaprasada I. B., 2004. Magnetic basement along the Jadcharla Vasco transect, Dharwar craton India. Current sciences. 86(11):1548-1553.

Udensi E. E., Usazuwa I. B., 2002., Two and half dimensional modeling of the major structure underlying the Nupe Basin Nigeria using Aeromagnetic data. Nigerian journal of physics. 14(1):55-61.

Ugwu, C. M, Ugwu, G. Z and Alasi, T. K., 2018. Spectral analysis and source parameter imaging of aeromagnetic anomalies over Ogoja and Bansara areas of lower Benue trough, Nigeria. Journal of Geology and Mining Research,10(3): 28-38. http://www.academicjournals.org/JGMR

Won J, Bevis M., 1987. Computing the gravitational and magnetic anomalies due to a polygon: ALGORITHM and FORTRAN subroutines, Geophysics. 52(2):232-238. 